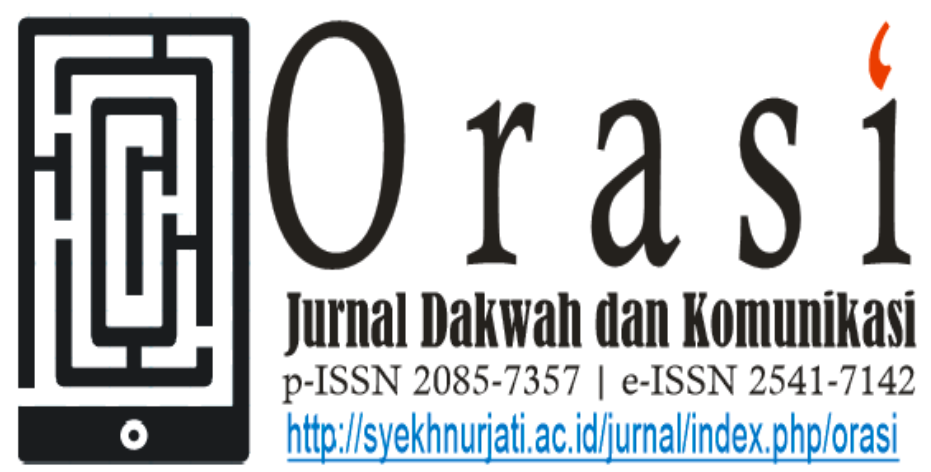

Volume 10 N0. 1 Juli 2019

\title{
KASUS PROSTITUSI ONLINE DALAM BINGKAI MEDIA
}

(Analisis Framing Zhongdang Pan dan Gerald M.Kosicki Terhadap Berita Kasus Revolusi Bisnis Syahwat Smart City Di Surat Kabar Harian Radar Cirebon Edisi 23 dan 24 Juli 2018)

\author{
Euis Ratnaningsih",a), Abd. Basit2,b) \\ ${ }^{1,2}$ Jurusan Komunikasi dan Penyiaran Islam, IAIN Syekh Nurjati Cirebon \\ Jl. Perjuangan By Pass Sunyaragi Cirebon

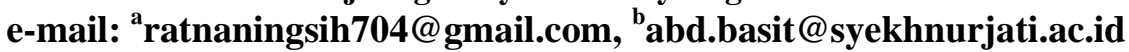

\begin{abstract}
Various reports of online prostitution cases have sprung up in all mass media, both electronic and print media. Like television, online portals, newspapers and so on. Media from the daily newspaper Radar Cirebon, including the one who reported the case of online prostitution. Daily newspaper Radar Cirebon reports on online prostitution based on geo location.

This study identifies how to report the case of the smart city lust business revolution in 23 and 24 July 2018 in the Radar Cirebon daily print media, and analyzes the news framing. The methodology used is qualitative research with the framing analysis approach of Pan and Kosicki models by analyzing the structure (syntax, script, thematic, and rhetorical), and using observation and documentation techniques in collecting data.

The results of the study show that; a) The reporting of the Smart City Business Revolution Revolution case is reported in full, little caution in delivering sentences because it leads to a tendency towards partiality to consumers and the government, in revealing the facts of the case. This happens because it is influenced by the interests of the media owner. b) Framing done by Radar Cirebon
\end{abstract}


is in accordance with the structure (syntax, script, thematic, and rhetorical) suggested by Zhongdang Pan and Kosicki.

Keywords: Framing, Newspapers, Online Prostitution

\begin{abstract}
ABSTRAK
Berbagai pemberitaan kasus prostitusi online banyak bermunculan di semua media massa baik media elektronik maupun cetak. Seperti televisi, portal online, surat kabar dan lain sebagainya. Media cetaksurat kabar harian Radar Cirebon termasuk salah satu yang memberitakan kasus prostitusi online tersebut. Koran harian Radar Cirebon memberitakan terkait prostitusi online yang berbasis geo lokasi.

Penelitian ini mengidentifikasi bagaimana pemberitaan kasus revolusi bisnis syahwat smart city pada edisi 23dan 24 Juli 2018 di media cetak harian Radar Cirebon, dan menganalisis framing berita tersebut. metodologi yang digunakan adalah penlitian kualitatif dengan pendekatan analisis framing model Pan dan Kosicki dengan menganalisis struktur (sintaksis, skrip, tematik, dan retoris), serta menggunakan teknik observasi dan dokumentasi dalam mengumpulkan data.

Hasil penelitian menunjukkan bahwa; a) Pemberitaan kasus Revolusi Bisnis Syahwat Smart City dilaporkan dengan lengkap, sedikit berhti-hati dalam penyampaian kalimat karena mengarah pada kecenderungan keberpihakan pada konsumen dan pemerintah, dalam mengungkap fakta kasus tersebut. Hal ini terjadi karena dipengaruhi oleh kepentingan pemilik media. b) Framing yang dilakukan Radar Cirebon telah sesuai dengan struktur (sintaksis, skrip, tematik, dan retoris) yang disarankan oleh Zhongdang Pan dan Kosicki.
\end{abstract}

Kata Kunci : Framing, Surat Kabar, Prostitusi Online

\section{Pendahuluan}

Media massa di berbagai negara pada dasarnya memiliki perkembangan yang berbeda-beda yang disebabkan karena sistem ekonomi dan politik negara yang bersangkutan. Media massa di negara-negara yang memiliki sistem kemasyarakatan yang tidak terlalu individualistik, komunal, sekuler atau masyarakat yang lebih religius, biasanya akan memiliki media massa yang berbeda dengan negara-negara barat dengan sistem politik dan ekonomi yang lebih liberal. Negara dengan ciri-ciri tersebut bahkan memiliki teori media dan praktik media yang berbeda (Morissan, dkk, 2013: 2).

Pesatnya

perkembangan teknologi informasi saat ini cukup memberikan kemajuan media massa yang signifikan. Media cetak ataupun elektronik saling bersaing kecepatan sehingga para pemburu berita dituntut kreativitasnya dalam penyampaian informasi. Penguasaan dasar -dasar pengetahuan jurnalistik merupakan modal penting ketika terjun ke dunia ini. Pengertian jurnalistik saat ini bukan hanya secara cetak, seperti surat kabar, majalah, dan sebagainya tetapi juga meluas menjadi media elektronik seperti radio atau televisi. Berdasarkan media yang digunakannya, meliputi jurnalistik cetak (print journalism), dan elektronik (electronic journalism). Akhir-akhir ini juga telah berkembang jurnalistik secara tersambung (online journalism) (Suryanto, 2015: 392).

Orasi: Jurnal Dakwah dan Komunikasi | Volume 10, No. 1, Juli 2019 
Berita adalah jendela dunia, melalui berita kita dapat melihat dan mengetahui apa yang terjadi. Tetapi apa yang kita lihat apa yang kita ketahui mengenai dunia itu tegantung pada apakah jendela yang kita gunakan besar atau kecil. Jendela yang besar dapat melihat lebih luas, sementara yang kecil membatasi pandangan kita. Apakah jendela itu berjeruji atau tidak.

Apakah jendela itu bisa dibuka lebar ataukah hanya dibuka setengahnya. Apakah lewat jendela itu kita bisa melihat secara bebas keluar ataukah kita hanya bisa mengintip dibalik jerujinya. Yang paling penting apakah jendela itu terletak dalam rumah yang punya posisi tinggi ataukah dalam rumah yang terhalang oleh rumah yang lain. Dalam berita, jendela itu adalah frame (bingkai) (Eriyanto, 2012 : 4)

Framing adalah metode untuk melihat cara bercerita (story telling) media atas peristiwa. Cara bercerita itu tergambar pada "cara melihat" terhadap realitas yang dijadikan berita. "cara melihat" ini berpengaruh pada hasil akhir dari konstruksi realitas. Analisis framing adalah analisis yang dipakai untuk melihat bagaimana media mengkontruksi realitas. Analisis framing juga dipakai untuk melihat bagaimana peristiwa dipahami dan dibingkai oleh media (Eriyanto, 2012: 10-11).

Praktik prostitusi melalui media elektronik atau media online saat ini tengah ramai diperbincangkan di masyarakat, terutama dilingkungan tempat tinggal peneliti. Masalah prostitusi adalah masalah yang rumit, oleh karena itu masalah ini sangat butuh perhatian khusus oleh masyarakat. Prostitusi sebuah bisnis yang identik dengan dunia hitam ini merupakan salah satu bisnis yang mendatangkan uang dengan cepat. Tidak memerlukan modal banyak, hanya dengan beberapa tubuh yang bersedia dibisniskan. Prostitusi. ${ }^{1}$

Berbagai pemberitaan kasus prostitusi online banyak bermunculan disemua media massa baik media elektronik maupun cetak. Seperti televisi, portal online, surat kabar dan lain sebagainya. Media cetak surat kabar harian Radar Cirebon termasuk salah satu yang memberitakan kasus prostitusi online tersebut. Koran harian Radar Cirebon meberitakan terkait prostitusi online yang berbasis geo lokasi. Hal ini termasuk terobosan baru dalam bisnis prostitusi online di kota Cirebon. Oleh sebabnya berita ini berjudul revolusi bisnis syahwat smart city. Koran harian Radar Cirebon memberitakan terkait kasus tersebut hingga 4 edisi. Yakni pada edisi 23 dan 24Juli 2018.

Penyajian berita dalam memaknai realitas perihal pemberitaan kasus revolusi bisnis syahwat smart city tersebut, tergantung bagaiamana media mengkontruksi realitas yang ada.

${ }^{1}$ Andika Dwiyadi. 2016. TINJAUAN

KRIMINOLOGIS TERHADAP KEJAHATAN PROSTITUSI MELALUI MEDIA ELEKTRONIK. Diakses dari PDF. https://core.ac.uk (diunduh pada tanggal 6 November 2018, pukul 09.21 WIB) 


\section{Metode Penelitian}

Penelitian ini merupakan penelitian kualitatif, penelitian kualitatif merupakan metode-metode untuk mengeksplorasi dan memahami makna yang oleh sejumlah individu atau sekelompok orang dianggap berasal dari masalah social atau kemanusiaan (Ahmad, 2015: 52).

Data primer yang digunakan dalam penelitian ini adalah teks berita revolusi bisnis syahwat smart city yang di sajikan surat kabar "Radar Cirebon" edisi 23 dan 24 Juli 2018.

Data sekunder atau pendukung dalam penelitian ini didapat dari buku, dan artikel di internet yang berkaitan dengan penelitian ini.

Dalam penelitian ini, akan menggunakan dua teknik pengumpulan data yaitu :

a. Observasi

Observasi adalah metode pengumpulan data yang diigunakan untuk menghimpun data penelitian melalui pengamatan dan pengindraan (Bungin, 2012: 118).

Penggunaan teknik observasi ini, peneliti terapkan untuk melihat dan membaca berita-berita yang terkait dengan kasus revolusi bisnis syahwat smart city yang ada dalam Koran harian radar cirebon . selain itu diterapkan pula untuk menganalisa sekaligus memaknai struktur teks berita, yang kemudian hasil analisa atau pengamatan tersebut dicatat secara sistematis.

b. Dokumentasi

Data dalam penelitian ini akan penulis kumpulkan menggunakan metode dokumentasi. Dokumentasi yaitu mencari data mengenai hal-hal atau variabel yang berupa catatan, transkip, buku, surat kabar, majalah, prasasti, notulen rapat, agenda dan sebagainya (Suharsimi, 1998:236).

Dokumen yang dikumpulkan dalam penelitian ini berupa teks-teks surat kabar radar Cirebon yang berisi berita tentang kasus revolusi bisnis syahwat smart city. Selain itu, dokumen berupa buku-buku referensi yang memiliki relevansi dengan penelitian ini.

Data-data tersebut tidak hanya penulis kumpulkan tetapi juga penulis olah sesuai dengan metodologi analisis framing yang digunakan. Data yang penulis maksud dalam penelitian ini adalah data primer yang telah disebutkan diatas.

Penelitian ini menggunakan pendekatan analisis framing. Analisis framing dipakai untuk membedah caracara atau ideologi media saat menkonstruksi fakta. Analisis ini mencermati strategi seleksi, penonjolan, dan pertautan fakta ke dalam berita agar lebih bermakna, lebih menarik, lebih berarti atau lebih diingat, untuk menggiring interpretasi khalayak sesuai perspektifnya. Dengan kata lain, framing adalah pendekatan untuk mengetahui bagaimana perspektif atau cara pandang yang digunakan oleh wartawan ketika menyeleksi isu dan menulis berita. Cara pandang atau perspektif itu pada akhirnya menentukan fakta apa yang diambil, bagian mana yang ditonjolkan dan dihilangkan, serta mau dibawa kemana berita tersebut (Sobur, 2014: 162).

Analisis framing termasuk ke dalam kategori paradigma 
konstruksionis. Paradigma ini memandang realitas kehidupan sosial bukanlah realitas yang natural, melainkan hasil dari konstruksi. Karenanya, konsentrasi analisis pada paradigma kontruksionis adalah menemukan bagaimana peristiwa atau realitas tersebut dikonstruksi, dengan cara apa konstruksi itu dibentuk. Dalam studi komunikasi, paradigma konstruksionis ini seringkali disebut paradigma produksi dan pertukaran makna (Eriyanto, 2011: 43).

Adapun langkah-langkah analisis model ini ada 4 struktur tahapan. Tahapan pertama adalah menganalisis struktur sintaksis (cara wartawan menyusun fakta). Caranya yakni dengan melihat bagaimana isi pada skema berita. Dalam struktur ini ada terdapat 4 unit analisis yang harus dianalisis yakni unit headline, lead, latar informasi, dan kutipan sumber. Setelah mengetahui hasil analisis pada struktur pertama, kemudian berlanjut ke tahapan kedua yakni menganalisis struktur skrip (cara wartawan mengisahkan fakta). Caranya adalah dengan melihat kelengkapan berita. Dalam tahap ini terdapat 6 unit analisis untuk mengetahui kelengkapan berita yaitu what (berita apa), where (dimana tempat peristiwa), when (kapan peristiwa terjadi), who (siapa yang melakukan), why(mengapa peristiwa terjadi), how (bagaimana peristiwa terjadi). Tahap ketiga tematik (cara wartawan menulis fakta). Caranya adalah dengan menuliskan bagaimana detil, koherensi, bentuk kalimat, dan kata ganti dalam tahap ini unit yang dianalisis adalah bagian Paragraf, proposisi atau kalimat, dan hubungan antarkalimat. Tahap keempat adalah retoris (Cara wartawan menekankan fakta) yakni dengan cara melihat gambar.

\section{Hasil dan Pembahasan}

Teks berita yang akan peneliti analisis adalah surat kabar yang ada pada edisi 23 Juli 2018 yang memberitakan tentang menguaknya prostitusi berbasis aplikasi geo lokasi di Kota Cirebon dan berita tentang pemantauan aparat kepolisian. Kemudian berlanjut di edisi 24 Juli 2018 yang memberitakan tentang rencana koordinasi aparat setempat untuk mengatasi kasus prostitusi online. Setelah itu, pada edisi 30 Juli 2018 memberitakan tentang mekanisme prostitusi online berjalan yang memuat dua berita. Terakhir pada edisi 31 Juli 2018 tentang penanggulangan mencegah prostitusi online berjalan. Maka ada empat edisi teks surat kabar yang dianalisis.

Berita-berita tersebut dianalisis dengan menggunakan model Framing Zhongdang Pan Dan Kosicki. Adapun judul-judul berita yang menjadi objek analisis adalah sebagai berikut:

Tabel 1. Daftar Berita 


\begin{tabular}{lrc}
\hline Surat Kabar & \multicolumn{1}{c}{ Judul Berita } & \multicolumn{1}{c}{ Edisi } \\
\hline \multirow{2}{*}{ Radar Cirebon } & $\begin{array}{l}\text { 1. Prostitusi Cirebon Kian Canggih } \\
\text { Berbasis Geo Lokasi } \\
\end{array}$ & Senolusi Bisnis Syahwat Smart City Juli 2018 \\
\hline & $\begin{array}{l}\text { 3. Koordinasi Untuk Atasi Prostitusi } \\
\text { Online }\end{array}$ & Selasa 24Juli 2018 \\
\hline
\end{tabular}

\subsection{Pemberitaan Edisi 23 Juli 2018 Berita 1}

Pada edisi dan berita satu ini, wartawan menceritakan investigasi terselubung yang dilakukan pada Kamis dan Jumat 19 dan 20 Juli 2018 terkait kasus prostitusi online yang berbasis geo lokasi. Dalam investigasi tersebut, wartawan tuangkan dalam bentuk cerita. Kemudian isi yang ada dalam pemberitaan tersebut adalah penjelasan atas proses penggunaan prostitusi online dengan aplikasi berbasis geo lokasi, selain itu tentang berapa tarif harga yang ditentukan, dan varian jasa yang ditawarkan oleh penyedia jasa. Wartawan menggiring pembaca untuk menginformasikan bahwa saat ini bisnis terlarang prostitusi online di Kota Cirebon sudah semakin canggih dan semakin mudah untuk dijangkau siapapun dan dimanapun.

Pada pemberitaan berita satu di edisi 23 Juli 2018, peneliti dapat melihat fokus berita yang diberitakan adalah mengulik gadis selaku penyedia jasa prostitusi online tersebut sudah merajalela. Wartawan tidak melakukan pengulikan terhadap para lelaki selaku konsumen prostitusi online tersebut, yang pada dasarnya praktik tersebut termasuk kedalam kategori kejahatan asusila. Praktik yang juga dapat menimbulkan tindak pidana lainnya.

\subsubsection{Analisis Framing Struktur}

\section{Sintaksis}

a. Headline

Dalam struktur headline wartawan menjelaskan prostitusi di Cirebon sudah semakin maju dari era sebelumnya, hal ini dijabarkan wartawan dengan menetapkan judul "Prostitusi Cirebon Kian Canggih Berbasis Aplikasi Geo Lokasi". Kata 'kian' menandakan adanya perubahan dari masa sebelumnya ke masa saat ini. Kemudian dipertegas dengan kalimat 'Berbasis Aplikasi Geo Lokasi' yang artinya, aplikasi dengan fitur geo lokasi merupakan salah satu wujud nyata perkembangan teknologi, yang berperan aktif untuk mengembangkan praktik prostitusi yang ada di Kota Cirebon. Kemudian kata "canggih" mencerminkan kehebatan dan kedahsyatan kemajuan praktik prostitusi di Cirebon yang menyiratkan hal tersebut tidak terjadi pada zaman sebelumnya.

b. Lead

Pada lead wartawan semakin menegaskan bahwa kecanggihan aplikasi berbasis geo lokasi adalah nyata. Bukan modus penipuan atau praktik abal-abal yang merugikan konsumen. Dengan kalimat “ 
Ternyata, ini disrupsi 'bisnis' prostitusi, wartawan menkankan bahwa aplikasi berbasis Geo lokasi merupakan akar dari bisnis prostitusi yang berkembang marak di kota Cirebon yang menggiurkan dan menguntungkan.

c. Latar Informasi

Wartawan tidak dengan sembrono mengungkapkan bahwa prostitusi sudah canggih dengan aplikasi berbasis geo lokasi. Latar belakang penelusuran pihak media terhadap kasus prostitusi Online berbasis geo lokasi selama dua hari yakni Kamis (19/7) dan Jumat (20/7) dijelaskan secara rinci adalah sebagai bukti bahwa praktik sedemikian hebat di kota Cirebon mema ng benar adanya dan sudah menyebar luas tanpa batas.

d. Pengutipan Sumber dan Pernyataan Wartawan mengutip pernyataan beberapa gadis penyedia jasa prostitusi online yang menjabarkan bagaimana kinerja prostitusi online dan menjelaskan beberapa model jasa yang disuguhkan sesuai keinginan gadis penyedia jasa prostitusi berbasis geo lokasi, adalah alasan yang menguatkan bahwa prostitusi online sudah sedemikian canggihnya hadir dan berjalan mulus di Kota Cirebon. Namun sayangnya, narasumber hanya kepada pihak gadis penyedia jasa saja, tidak menyeimbangkan dengan sumber dan pernyataan dari konsumen atau penikmat yang menerima jasa praktik prostitusi online tersebut.

e. Penutup
Wartawan menutup berita dengan kesimpulan bahwa wartawan hanya Sekedar untuk membuktikan, penelusuran selama dua hari cukup untuk menguak fakta bahwa prostitusi di Kota Cirebon ini sudah sedemikian canggihnya. Semakin mudah menjangkaunya. Sangat privat, bersembunyi di tengah hiruk pikuk metropolitan. Beroperasi dalam keheningan memanfaatkan kelengahan para aparat. Sementara di alam maya, agresifitasnya bagai lebah, menyengat.

\subsubsection{Analisis Framing Struktur Skrip}

Dari perangkat skrip pada bagian berita ini terbilang lengkap karena dapat menjawab unsur -unsur yang terdapat pada struktur skrip ini, terutama bagian why dan how dijelaskan secara gamblang bagaimana cara prostitusi online beroprasi yaitu berawal dari pelaku yang melek teknologi yang mengerti cara mengoprasikan fitur berbasis lokasi yang memang unik, penggunaannya cukup menekan tulisan "lihat sekitar". Di situ akan ditemukan sesama pengguna aplikasi ini, setelah itu konsumen bebas memilih sesuai selera. Kemudian lengkap dijabarkan mengapa prostitusi online dapat berkembang pesat. Yaitu Karena layanan pesan instan berbasis geo lokasi asal Thailand yang sangat membantu sekaligus karena kelengahan aparat hukum sehingga praktik prostitusi beroprasi dengan lancar, juga serta karena penggunaan yang diselewengkan. Namun sayangnya pada unsur who wartawan hanya menjelaskan bagaimana investigasi si penyedia jasa atau dalam hal ini "si perempuan" saja yang tertera. 
Untuk para "lelaki hidung belang" selaku konsumen tidak ada keterangan lebih rinci termasuk tidak diinvestigasi.

\subsubsection{Analisis Framing Struktur}

\section{Tematik}

Secara tematik, dari paragraf awal hingga akhir wartawan rinci menceritakan pengalaman yang dimiliki. Dari mulai cara pengoprasian aplikasi, harga hingga proses yang terjadi dalam praktik prostitusi online. Bahkan wartawan tidak melakukan pada satu dua orang untuk mebuktikan bahwa prostitusi online marak berkeliaran di area kota Cirebon. Hal tersebut menunjukkan bahwa wartawan sungguhsungguh ingin menguak fakta bahwa bisnis ini sudah cukup populer dalam kelengahan aparat hukum. Dan dari kesembilan belas paragraf yang di paparkan dalam surat kabar edisi 23 Juli 2018 tersebut, wartawan hanya fokus menelusuri bagaimana gadis penyedia prostitusi berkeliaran, tidak ditelusuri dan diinvestigasi atau bagaimana para lelaki selaku konsumen yang turut andil dalam praktik negative tersebut.

\subsubsection{Analisis Framing Struktur}

\section{Retoris}

Wartawan menggunakan ilustrasi gambar wanita berpakaian membuka bagian pundak dan lehernya yang menutupi bagian matanya dengan telepon genggam dengan matanya digambarkan berada di dalam telepon genggam, dengan ukuran yang sangat besar dimuka surat kabar, menyiratkan makna wartawan ingin menunjukkan bahwa dibalik telepon genggam, kemudian kuku pada tangan yang menggenggam ponsel pintar tersebut di cat dengan warna merah mengisyaratkan wanita terawat nan cantik juga menarik, tak kalah poles bibir dengan agak terbuka, mengesankan kesan seksi untuk memikat para pelanggan, tersebut merupakan ilustrasi gambaran penyedia jasa prostitusi online beroprasi dengan hening, dan agresifitas dalam ponsel genggam yang menjadi modal mereka, mengundang syahwat yang panas di tengah hiruk pikuk kota Cirebon dengan kelengahan aparat hukum. Hal ini merupakan usaha media dalam menarik perhatian khalayak.

\subsection{Pemberitaan Edisi 23 Juli 2018 Berita 2}

Dalam edisi 23 Juli terdapat dua berita yang dipaparkan. Keduanya sama -sama memberitakan bahwa kemajuan teknologi berupa aplikasi berbasis geo lokasi keberadaannya sudah kelewat canggih menyalip kemajuan kota Cirebon itu sendiri. Karena pada dasarnya merupakan satu edisi berita, meskipun dibedakan menjadi dua judul, namun dalam konten antara judul berita satu dengan berita dua tetap dengan substansi yang sama. Ada sedikit perbedaan Pada berita dua ini. Wartawan menggiring pembaca bahwa Dinas Komunikasi Informatika dan Statistik, memaparkan bahwa mereka tidak berwewenang untuk menindak lanjuti kasus prostitusi online.

Berita dua ini lugas mengutip pernyataan sekretaris DKIS Maruf Nuryasa bahwa mereka tidak memiliki wewenang bertindak atas kemajuan praktik revolusi bisnis syahwat smart city. Sisi tegas lainnya wartawan hanya menginvestigasi pihak gadis penyedia jasa prostitusi online. Tidak beserta pihak sebelahnya yakni para pemakai 
atau konsumen jasa prostitusi online berbasis geo lokasi. Hal tersebut jelas terpapar pada isi berita.

\subsubsection{Analisis Framing Struktur} Sintaksis

a. Headline

Berita yang terdapat pada edisi yang sama dengan judul sebelumnya ini, wartawan sengaja memisahkan berita sebelumnya dengan berita ini. Hal tersebut dapat dilihat dijudul berita ini. Pada judul berita "Revolusi Bisnis Syahwat Smart City" wartawan bermaksud mengambarkan kecanggihan bisnis prostitusi yang lebih maju ke depan dari sebelumnya. Karena saat ini praktik prostitusi online sudah menggunakan aplikasi berbasis geo lokasi. Hal ini ditunjukkan pada kalimat "Revolusi bisnis Syahwat" kalimat tersebut menyiratkan perubahan bisnis yang terlampau jauh dan berbagai macam modus kejahatan bisnis prostitusi online. Kemudian kalimat "smart city" adalah alat nyata yang mengerikan atas keberadaanya.

b. Lead

Lead pada bagian ini, semakin menegaskan bahwa kota Cirebon dalam posisi yang mengkhawatirkan karena kasus prostitusi online kecanggihan teknologi tersebut. Kalimat "Sebuah pendekatan yang memanjakan pelanggan, sekaligus memberi jaminan untuk tidak terciduk razia aparat." Menggambarkan bahwa betapa mudahnya kejahatan prostitusi menjalar di kota Cirebon, sekaligus menunjukkan bahwa aparat hukum sudah kecolongan untuk membiarkan praktik ini lolos hingga menyebar luas.

c. Latar Informasi

Latar belakang layanan pesan berbasis geo lokasi yang luput dari pantauan bukan kali ini saja disalahgunakan. Tapi yang satu ini sudah kelewat canggih menyalip "kemajuan" kota Cirebon. Dinas Komunikasi Informatika dan Statistik (DKIS) Kota Cirebon tak punya wewenang melakukan penindakan. kewenangan penindakan bukan di daerah, adanya di KOMINFO (Kementrian Informatika dan Komunikasi).

d. Kutipan Sumber dan Pernyataan Wartawan mengutip pernyataan Dinas Komunikasi Informatika dan Statistik (DKIS) Kota Cirebon yang menyatakan bahwa DKIS tidak berwenang untuk bertindak apa apa karena wewenang hanya ada pada pusat KOMINFO (Kementrian Informatika dan Komunikasi) adalah bentuk penguatan bahwa lemahnya perlindungan kejahatan prostitusi untuk masyarakat kota Cirebon.

e. Penutup

Wartawan menutup berita dengan kesimpulan Maruf menghimbau agar masyarakat berpartisipasi aktif. Turut melaporkan aplikasi maupun penyalahgunaan yang dirasa meresahkan. Salah satunya bisa melalui aduankonten.id. "Daftar terus bisa melaporkan situs, wesite, akun media social, aplikasi mobile, dan softwere yang masuk criteria bermuatan negative". Katanya. 


\subsubsection{Analisis Framing Struktur} Skrip

Dalam struktur skrip ini wartawan lengkap menjelaskan waktu sejak kapan revolusi bisnis syahwat ini hadir, mengapa revolusi bisnis syahwat ini hadir, dan sekaligus dapat memberikan contoh bagaimana alur proses revolusi praktik prostitusi online di Kota Cirebon. Menjelaskan pula besaran harga yang ditentukan penyedia jasa prostitusi yang menggunakan aplikasi tersebut.

\subsubsection{Analisis Framing Struktur}

\section{Tematik}

Secara tematik, dari paragraf awal hingga paragraf akhir, wartawan jelas berusaha menekankan bahwa bisnis ini benar-benar baru dan menghwatirkan masyarakat, terlebih tidak ada aparat yang dapat dimintai pertanggungjawaban atas kekhawatiran tersebut.

\subsubsection{Analisis Framing Struktur}

\section{Retoris}

Wartawan menggunakan gambar ilustrasi sepasang kaki wanita yang mengenakan heels kemudian Nampak sepasang kaki tersebut sedang melangkah maju, dengan pakaian jauh diatas lutut, dan meletakkan kalimat penjelas "Kerja Prostitusi Berbasis Geolokasi" berwarna merah tebal disisi gambar ilustrsi sepasang kaki wanita tersebut, menunjukkan bahwa wartawan ingin memaparkan bahwa seperti itulah wanita jalang menjalankan praktik prostitusi ini, hingga menyebar luas dan canggih di tengah kalangan masyarakat.

\subsection{Pemberitaan Edisi 24 Juli 2018}

Dengan judul "Koordinasi untuk atasi prostitusi online" edisi 24 Juli 2018 ini memberitakan bahwa praktik prostitusi online ini kehadirannya meresahkan masyarakat. Maka kemudian diperlukan koordinasi seluruh elemen baik masyarakat, lembaga-lembaga, ataupun aparat pemerintah yang terkait dengan kasus prostitusi online tersebut. Dengan judul demikian, pembaca akan mengira hal tersebut merupakan tindakan real yang dilakukan. Namun ternyata dalam pemberitaan hanya diberitakan terkait dan rencana. Terlebih lagi, hanya cenderung saran yang ditujukan kepada masyarakat umum, yang mengisyaratkan, kasus ini dapat sedemikian pesatnya karena masyarakat yang tidak berperan aktif, dan seolah menyudutkan hanya masyarakatlah yang bertanggung jawab atas kasus tersebut.

Berita ini juga memaparkan sejarah dari awal kehadiran prostitusi online di Kota Cirebon yang mulanya tidak ada, hingga menjadi berkembang pesat, melebihi kecanggihan Kota Cirebon itu sendiri.

\subsubsection{Analisis Framing Struktur} Sintaksis

a. Headline

Surat Kabar edisi 24 Juli 2018 ini, berjudul Koordinasi untuk Atasi Prostitusi Online, pemilihan kata "koordinasi" ini mengesankan bahwa prostitusi online ini cukup besar dan bukan masalah yang mudah diselesaikan karena itu dibutuhkan gabungan beberapa pihak yang berwewenang untuk memusnahkan virus tersebut. Setelah itu, pemilihan kata "atasi" pada judul tersebut mengisyaratkan bahwa kasus prostitusi online bukan hal sepele, sebab itu harus diatasi dalam artian harus diselesaikan. 
b. Lead

Pada bagian lead ini, wartawan menjelaskan bahwa kehadiran praktik prostitusi online tersebar melalui aplikasi canggih. Yang berarti bahwa, orang lain tidak dapat membuktikan kejahatan pelaku prostitusi online tersebut secara tangkap tangan langsung. Kemudian untuk meyakinkan khalayak bahwa kasus prostitusi adalah hal yang kian meresahkan, wartawan melakukan investigasi terselubung, guna menguak fakta bahwa penggunanya cukup marak. Sebab itulah lead pada teks ini, menekankan bahwa wartawan melakukan investigasi sebelum melaporkan kepada khalayak.

c. Latar Informasi

Dengan maraknya prostitusi online wartawan menggiring latar informasi berita edisi ini tersumber dari penyalahgunaan para pengguna aplikasi pesan instans berbasis geolokasi teresbut.

d. Pengutipan Sumber dan Pernyataan Sosok dosen e-comerce sekaligus konsultan teknologi informasi diangkat oleh wartawan untuk memberikan pernyataan terkait prostitusi online tersebut, merupakan salah satu upaya wartawan meyakinkan khalayak agar kasus ini segera mendapatkan solusi. Wartawan memperkuat dengan pernyataan aparat sat pol pp yang akan mengadakan koordinasi dengan sejumlah pihak terkait.

e. Penutup

Dalam penulisan penutup wartawan mempertegas bahwa aparat terkait akan melakukan usaha memperbaiki kasus prostitusi online termasuk aparat menyampaikan mengajak masyarakat agar ikut serta andil untuk melaporkan. Hal tersebut jelas wartawan menggiring masyarakat ikut untuk membasmi prostitusi online yang sebarkan oleh pengguna aplikasi pesan instans berbasis geo lokasi.

\subsubsection{Analisis Framing Struktur \\ Skrip}

Dalam struktur Skrip Edisi berita ini termasuk hampir lengkap karena pada berita ini dapat menjawab apa yang terjadi yaitu adanya rencana koordinasi atasi prostitusi online, berita ini juga menjelaskan mengapa harus diadakannya koordinasi atasi kasus prostitusi online namun sayangnya berita ini hanya menjawab bagaimana yang seharusnya masyarakat namun tidak menjelaskan hal apa yang akan dilakukan aparat pemerintahan untuk mengatasi kasus prostitusi online tersebut.

\subsubsection{Analisis Framing Struktur} Tematik

Secara Tematik, pada setiap paragrafnya disampaikan secara runtut. Mulai dari hal yang meresahkan masyarakat yakni praktik prostitusi online, kemunian mengenai penyebabnya hingga saran yang harus dilakukan masyarakat yang disarankan oleh konsultan teknologi informasi juga harapan kepada aparat pemerintah agar memberi perhatian lebih kepada kasus ini. Sedikit terjawab oleh ketua sat pol pp yang akan melaksanakan koordinasi termasuk dengan polisi. Namun 
sayangnya tidak dijelaskan apa upaya yang akan dilakukan.

\subsubsection{Analisis Framing Struktur}

\section{Retoris}

Dalam berita edisi 24 Juli 2018 ini, wartawan menyertakan unsur grafis dalam retoris. Kalimat "koordinasi untuk atasi prostitusi online" dicetak tebal dan besar. Merupaka upaya penekanan fakta yang seharusnya terjadi di dalam realitas masyrakat di Kota Cirebon.

\section{Simpulan}

Berdasarkan hasil penelitian dan pembahasan mengenai analisis framing dari empat edisi berita Radar Cirebon yaitu edisi 23,24,30, dan 31 Juli 2018, mengenai kasus Revolusi Bisnis Syahwat Smart City, maka pada bagian ini penulis menarik kesimpulan sebagai berikut;

a. Pemberitaan kasus Revolusi Bisnis Syahwat Smart City dilaporkan dengan lengkap, namun sedikit berhati-hati dalam penyampaian kalimat, karena mengarah pada kecenderungan keberpihakan pada pihak konsumen dan pemerintah. Kecenderungan Keberpihakan pada pemerintah terkait dan pelanggan jasa prostitusi atau konsumen yang ditunjukan dengan cara menyudutkan gadis penyedia jasa, karena hanya menginvestigasi sebelah pihak yakni pada pihak perempuan penyedia jasa dalam mengungkap fakta kasus revolusi bisnis syahwat smart city tersebut. Sedangkan pihak laki-laki atau pembeli jasa prostitusi online selaku sesama pelaku yang melakukan praktik syahwat terlarang melalui aplikasi smart city tersebut tidak turut diinvestigasi.

b. Framing yang dilakukan Radar Cirebon telah sesuai dengan struktur (sintaksis, skrip, tematik, dan retoris) yang disarankan oleh Zhongdang Pan dan Kosicki.

\section{Daftar Pustaka}

Ahmad, Jalaluddin. (2015). Metode Penelitian Administrasi Publik Teori dan Aplikasi. Yogyakarta: Gava Media.

Bungin, Burhan. (2011). Konstruksi

Sosial Media Massa. Jakarta

Timur: Prenada Media Grup

(Kencana).

Eriyanto. (2012). Konstruksi, Ideologi, dan Politik Media. Yogyakarta:

LKiS Group.

Morissan. (2013). Teori Komunikasi

Massa. Bogor: Ghalia Indonesia.

Sobur, Alex. Analisis Teks Media.

Bandungg: PT. Remaja

Rosdakarya.

Suharsimi, A. (2004). Prosedur

Penelitian Suatu Pendekatan

Praktek. Yogyakarta: Rineka

Cipta, 1998.

Suryanto. (2015). Pengantar Ilmu Komunikasi (1). Bandung: CV Pustaka Setia.

Internet:

Amelia Lutfiatin Nikmah, 2015, PEMBERITAAN KASUS PENUTUPAN LOKALISASI PROSTITUSI DOLLY

(Analisi Framing Pada Surat Kabar Republika dan Kompas Pada Edisi Juni 2014) http://www.eprints.walisongo.ac. 
Euis Ratnaningsih, Abd. Basit | Kasus Prostitusi Online...

id.google.co.id (diakses pada tanggal 19 Agustus 2018, Pukul 23.39).

Widya Sulistiana, 2016, ANALISIS PEMBINGKAIAN BERITA TENTANG PENERTIBAN LOKASI PROSTITUSI dan PERJUDIAN KALIJODO OLEH PEMPROV DKI JAKARTA (Di Surat Kabar Pos Kota dan Warta Kota Edisi Februari 2016).

https://www.repository.ubharaja ya.ac.id/ (Di Akses Pada Tanggal 20 Agustus 2018, Pukul 11.33). 